\title{
Referentiality and telicity in Lakhota and Tagalog
}

\author{
Anja Latrouite \& Robert D. Van Valin, Jr.
}

In this paper we look at the way referentiality and telicity are encoded in Lakhota and Tagalog, two unrelated, morphologically rich languages that exhibit both a determiner system and rich verbal marking. The main question centers on how noun phrase marking and verb marking interact in these languages to generate a telic or an atelic interpretation of incremental theme verbs. The analysis by and large supports Filip's (1993/1999) claim that telicity is 'calculated' based on a number of interacting factors.

\section{Introduction: referentiality and telicity*}

It has been noted time and again that there is a link between the telicity of incremental predicates and the referential status of undergoer arguments (cf. Verkuyl 1972, Krifka 1986, 1989, 1992, Filip 1993/1999, Filip \& Rothstein 2005). The acceptablity of time-span adverbials like in an hour is commonly viewed as a good test for telicity. As the examples in (1a) and (2a) show, bare plural or mass nouns in object position always yield an atelic reading with incremental verbs and are clearly not compatible with time-span adverbials of the in an hour type. They go well with for-adverbials, however, which also denote a time-span, albeit without any implication that the event must be completed. In contrast, plural noun and mass noun undergoers with definite articles (cf. (1b) and (2b)) yield a telic reading with incremental verbs and sound better with in-adverbials than with for-adverbials. Note that the telic reading is not absolutely required by the definite article, how-

* We would like to thank two anonymous reviewers for helpful comments on an earlier draft. We would also like to thank our Lakhota language consultant Della Bad Wound as well as our Tagalog language consultants Reyal Panotes, Redemto Batul and Jeruen Dery. This research was supported in part by CRC 991 'The structure of representations in language, cognition and science'. 
ever. Atelic readings and thus for-adverbials seem to be marginally acceptable, if the undergoer can be understood as denoting a kind rather than a specific and uniquely identifiable object in a given context. ${ }^{1}$

(1) a. I drank milk *in an hour/ for an hour.

b. I drank the milk in an hour/?? for an hour.

(2) a. I built wooden houses * in 10 years/ for ten years.

b. I built the wooden houses in ten years/ (?)for ten years.

Thus the crucial factor is being referential rather than being marked by a definite article per se. The explanation as to why there should be a link between referentiality and telicity goes back to Krifka (1986, 1989, 1992), who proposes that for a certain class of verbs (incremental theme verbs) there is a one-to-one relationship between parts of the event and parts of the referent of the related undergoer arguments, e.g. when we drink a particular drink, then parts of this drink decrease in lockstep with the progress of the drinking event. In that way, there is a homomorphism between the undergoer argument and the event, as every part of the drink being drunk corresponds to a part of the drinking event. The homomorphism hypothesis motivates the influence of the undergoer arguments on the interpretation of the verbal predicates. The idea is that if the undergoer (object) argument is conceived as uniquely identifiable, and thus bounded and occurs with a homomorphic predicate, then the event into which it is mapped will be interpreted as bounded, i.e. telic, too. Therefore, undergoer arguments that are expressed by plural and mass nouns require either a specific quantifier or article to be interpretable as referring to a quantized amount, i. e. as a precise amount measuring out the event from the beginning to the end, as exemplified in (3).

(3) a. I drank their beer for an hour/ in an hour.

b. I drank the milk ??for an hour/ in an hour.

c. I drank three liters of milk * for an hour/ in an hour.

d. I drank the three liters of milk ??for an hour/ in an hour.

1 An appropriate context for (2b) would be: I have been in the house building business for years and started out with building wooden houses. I built the traditional wooden houses for ten years, then I started building concrete houses like everyone else. For (1b) it is harder to conceive of a context, possibly: They gave me ten liters of goat milk to cure my stomach problems. I drank the milk for an hour, then I turned to beer and whisky again. 
The data support the claim that the hallmark of definiteness marking in languages like English is uniqueness, as suggested by Löbner (1985), rather than familiarity, as suggested by Heim (1991). While the possessive NP in (3a) suggests familiarity, it does not impose uniqueness the way the definite article does, and therefore the NP may be interpreted as quantized or not. The possessive NP their beer can be interpreted as either unique, e.g. the particular beer that Sam and Bill have in their refrigerator (quantized), in which case in an hour is appropriate, or as nonunique, i. e. as any liquid that can be labeled as 'beer' that they happen to have (non-quantized), and in this case for an hour works.

Thus apart from inherently atelic and telic verbs, there is a class of verbs that like telic verbs determine a culmination condition, but unlike telic verbs do not imply a culmination requirement, like write, knit, eat, paint, read, build, drink, and therefore are understood as atelic, unless further morphosyntactic (or contextual) clues are given. ${ }^{2}$ As is well known these markers may differ quite substantially from language to language. Most importantly they may be either found on the verb, e. g. in terms of perfectivity markers (Filip 1993/1999), or within the noun phrase as definiteness or case markers (Ramchand 1997, Kratzer 2004, Filip \& Rothstein 2005), leading to the question as to what exactly the components of telicity are (see also Fleischhauer \& Czardybon, this volume).

In this paper we explore two unrelated languages, Lakhota and Tagalog, that have also been claimed to employ markers on the verb to yield telic interpretations (cf. Saclot 2011), albeit not perfectivity markers, but rather markers that indicate certain semantic properties of the undergoer argument: in the case of Tagalog the semantic role and in the case of Lakhota the specificity. On top of that both languages exhibit a determiner system. In the main part of the paper we investigate the division of labour between the verb stems and the respective markers to achieve telicity.

2 This is true for dependent-marking accusative languages like English, German and Russian. In many ergative languages, however, the base forms of these verbs are telic and the atelic uses are derived via e. g. antipassivization; see Van Valin \& LaPolla (1997), §3.2.3.3 for discussion. Neither Lakhota nor Tagalog fits easily into a simple accusative-ergative dichotomy. 


\section{The encoding of specificity and definiteness in Lakhota}

Lakhota is a Siouan language spoken in the northern Great Plains of North America. It is verb-final, right-branching and thoroughly head-marking. This is exemplified in (4). ${ }^{3}$

(4) a. Wičháša ki hená wówapi ki Ø-wičhá-wa-k’u. man the those book the INAN-3plANIMU-1sgA-give 'I gave the book to those men.'

á. Wičháwak'u.

'I gave it to them.'

b. Wičháša ki hená matȟ́ way Ø-Ø-kté-pi man the those bear a 3sgU-3A-kill-PL 'Those men killed a bear.'

b'. Ktépi.

'They killed him/her/it.'

Basic word order is SOV, and subject and object are cross-referenced on the verb, with the consequence that the verb word alone can constitute a complete clause, as in $\left(4 a^{\prime}, b^{\prime}\right)$. Subject cross-reference follows a split-intransitive pattern, with some intransitive verbs taking actor (nominative) coding and others taking undergoer (accusative) coding. As these examples show, the language has definite and indefinite articles, as well as demonstratives. In fact, it has an extremely rich determiner system, with two definite articles, nine distinct indefinite articles, and nine demonstratives (NLD: 815). We introduce each type of article.

Lakhota has two definite articles, $k i(\eta)$ 'the' vs. $k$ 'un 'the aforementioned', e. g. wówapi ki 'the book(s)' vs. wówapi k'uy 'the aforementioned book(s)'; like English the, they are neutral with respect to number. The basic definite article, $k i(\eta)$, has both deictic and anaphoric uses. In contrast, $k$ 'u 'the aforementioned' has only anaphoric uses, and it can only mark a nominal whose referent has been previously mentioned. Discussion will be restricted to $k i(\eta)$ from here on, since it is overwhelmingly the most commonly occurring definite article, due to the strong contextual restriction on $k^{\prime} u \eta$.

\footnotetext{
3 Abbreviations: A 'actor', ANIM 'animate', AV 'actor voice', DAT 'dative', GEN 'genitive', INAN 'inani-mate', IPFV 'imperfective', LK 'linker', MOD 'modifier', NEG 'negation', NLD 'New Lakota Dictionary' (Ullrich 2011), NOM 'nominative', NSO 'non-specific object', PL/pl 'plural', POT 'potential', PSA 'privileged syntactic argument', $Q$ 'interrogative marker', RLS 'realis', sg 'singular', STAT 'stative', U 'undergoer', UV 'undergoer voice'.
} 
There are nine indefinite articles, which fall into three major classes: specific, non-specific and negative. Within each class there are distinctions for singular vs. plural, and within the negative class, plural animate (further, human vs. nonhuman) vs. inanimate, and non-countable are distinguished. Specific indefinites are referential, while non-specific indefinites are not. There is therefore no possible ambiguity in a sentence like I'm looking for a book in Lakhota like there is in English; each of the two possible readings of $a$ book in English would be signaled by distinct indefinite articles, as in (5).
a. Wówapi way
$o<\varnothing-w a ́>l e$.
[olé 'look for']
book a[+specific] look.for $<$ INAN-1sgA $>$
'I'm looking for a [particular] book.'
b. Wówapi wayží $\quad 0<\varnothing$-wá>le.
book a[-specific] look.for $<$ INAN-1sgA>
'I'm looking for a book [any book will do].'

The non-specific indefinite articles can occur with intensional verbs like e. g. want or look for, with verbs carrying the hypothetical-conditional marker $-k t A,{ }^{4}$ and as the focus of a yes-no question. The negative indefinite articles occur in the scope of negation. The system of indefinite articles is summarized in Table 1, from Rood \& Taylor (1996).

\begin{tabular}{l|l|l|l} 
& Specific & Non-specific & Negative \\
\hline Singular & wan & wanží & wanžíni \\
\hline Plural & & & \\
Animate & & \\
Human & eyá & etán & tuwéni \\
Non-human & eyá & etán & tákuni \\
Inanimate & eyá & etán & tákuni \\
\hline Non-countable & eyá & etán & etánni
\end{tabular}

Table 1: Lakhota indefinite articles

The specific and non-specific indefinite articles make only a singular vs. plural distinction, while the most distinctions are found among the negative indefinite articles, all of which end in -ni, which is clearly related to the negative morpheme

4 The capital $A$ indicates that the vowel undergoes ablaut in various contexts (NLD: 754); it can appear

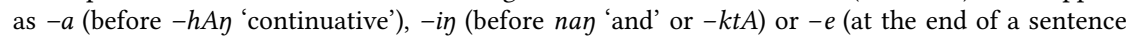
or before ( $k$ ')éyaš 'but'). It contrasts with the final $a$ in verbs like yawá 'read', which is invariable. 
-šni. The human and non-human/inanimate forms are based on tuwé 'be who, someone' and táku 'what, something'.

\section{Lakhota verbs, verb morphology and telicity}

The verbal systems in Lakhota and Tagalog differ significantly, in that Lakhota lacks voice, while Tagalog has a rich voice system (see §5). Accordingly with a transitive verb the actor is always the subject and the undergoer always the object. Because Lakhota is a strictly head-marking language, the actor and the undergoer are coded on the verb, as illustrated in (6). What (6a, b) also illustrate is that third person, both actor and undergoer, is not expressed by a phonological form and is represented by ' $\varnothing$ ' in the morphemic segmentation. Only thirdperson plural animate undergoers have an overt marker, wičha- ${ }^{5}$ Despite the lack of a phonological form, Lakhota verbs take specific third-person actors and undergoers and third arguments of three-place predicates as well, as (6) shows.

$$
\begin{aligned}
& \text { a. } \varnothing-\varnothing-\varnothing-K^{\prime} \text { '́. [cf. (4a, a')] } \\
& \text { INAN-3sgU-3sgA-give } \\
& \text { 'He/she gave it to him/her.' }
\end{aligned}
$$

b. Ø-Ø-Kté. [(cf. $\left.\left(4 b, b^{\prime}\right)\right]$

3sgU-3sgA-kill

'He/she/it[ANIm] killed him/her/it[ANIm].'

The third-person arguments in these sentences have specific discourse referents, as the translations make clear. The third-person argument markers, with or without phonological form, are not pronouns, as argued in Van Valin (2013), for two reasons (see also Austin \& Bresnan 1996). First, they can be bound locally, as in (4a, b), while pronouns cannot be so bound, and second, they can cross-reference indefinite NPs, as in (4b) and (5), something which should not be possible with pronouns, which are inherently definite. Van Valin argues that the bound argument markers are specific rather than definite, which makes them compatible with the specific indefinites introduced in $\S 2$; this specific reference can be cancelled only in a small set of grammatical contexts, the same ones in which the non-specific indefinite articles occur, which were mentioned in $\S 2$. The interpretation of the argument markers as pronouns in (6) could be the result of a Gricean

5 The number of plural animate subjects and non-third-person animate objects is expressed by the suffix $-p i$, as in (4b); the number of plural inanimate subjects of stative verbs is expressed by reduplication of the verb. 
implicature: the use of the bound form alone to signal a referent indicates to the hearer that the speaker believes that the hearer is able to uniquely identify the referent. Pronominal affixes are interpreted as definite, when they occur without an accompanying NP, because the implicature is that they refer to an identifiable referent, and identifiability and referentiality are the key ingredients of the concept of definiteness (Löbner 1985).

Lakhota has limited tense-aspect inflection. There is no inflectional coding for past tense, and therefore a verb can be interpreted as either present or past tense, as in (7) below. If one wanted to explicitly indicate that an action was on-going and continuing, then the aspect marker $-h A \eta$ 'continuative' could be added to the verb, e.g. yúta-he 'he/she is/was eating' [yútA 'eat']. Particularly significant for the discussion of telicity is the fact that there is no marker of perfectivity. If one wanted to signal that an action had not yet occurred or was hypothetical, then $-k t A$ can be used, e. g. yútin-kte 'he/she will/would eat'. (Rood \& Taylor See 1996: 474, NLD: 821-22.)

In English and many other languages it is possible with activity verbs like eat to simply drop the direct object, but not surprisingly this is not possible in Lakhota, since dropping the object NP does not affect the specificity of the object argument, as shown in (7).

(7) a. Hokšila ki aǧúyapiskuyela ki Ø-Ø-yúte.

boy the cookie the INAN-3sgA-eat

'The boy is eating/ate the cookie.'

b. Hokšila ki aǧúyapiskuyelaway $\quad$-Ø-yúte.

boy the cookie a[+specific] INAN-3sgA-eat

'The boy is eating/ate a [certain] cookie.'

c. Hokšila ki Ø-Ø-yúte.

boy the INAN-sgA-eat

'The boy is eating/ate it', 'The boy is eating/ate'.

The transitive verb yútA 'eat' is interpreted as having a specific object, regardless of whether there is an overt object or not, just as in the examples in (6). If one wants to use a transitive verb intransitively, there are two options. First, it can be prefixed with the non-specific object marker wa-, and it cannot have an overt object NP of any kind.

(8) a. Hokšila ki w-Ø-óte. $\quad[w a-+y u ́ t A=$ wótA $]$

boy the NSO-3sgA-eat

'The boy is eating/ate', *'The boy is eating/ate it'. 


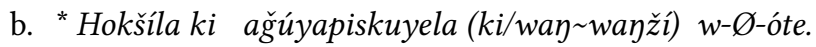
boy the cookie the/a[ \pm specific] NSO-3sgA-eat

'The boy is eating/ate (the/a [certain]) cookie.'

Second, the object noun can be incorporated, yielding an intransitive construction.

(9) Hokšila ki aǧúyapi Ø-yúte.

boy the bread 3sgA-eat

'The boy is eating/ate bread.'

According to DeReuse (1994), noun incorporation in Lakhota does not always involve phonological integration of the noun with the verb; rather, the semantic effect of incorporation can be achieved by 'stripping' the noun of all modifiers and placing it immediately before the verb, as in (9). The noun is non-referential and does not have the status of a direct object in a non-incorporated construction like (7a, b).

The standard test for telicity is compatibility with in vs. for temporal modifiers, as illustrated in (3). Atelic predications are compatible only with for-phrases, while in-phrases are compatible only with telic predications. This test can be applied in Lakhota, as there is an optional marker corresponding to in, imáhel 'in, within, inside of'; there is, however, no marker corresponding to for. Temporal expressions can also occur without any marker, and in such instances one must rely on the translation into English for the in vs. for contrast, as exemplified in (10).
a. Wičháša ki oápȟe wayží ağúyapi way $\varnothing-\varnothing$-yúte. man the hour one bread a[+specific] INAN-3sgA-eat 'The man ate a (loaf of) bread in/* for an hour.'

á. Wičháša ki oáphe wayží imáhel ağúyapi way Ø-Ø-yúte. man the hour one within bread a[+specific] INAN-3sgA-eat 'The man ate a (loaf of) bread in/ ${ }^{*}$ for an hour.'

b. Wičháša ki oápȟe wayží w-Ø-óte. man the hour one NSO-3sgA-eat 'The man ate for ${ }^{*}$ in an hour.'

As noted in $\S 1$, it has been claimed that there are verbs which are inherently telic, e. g. hit, verbs which are inherently atelic, e. g. see, think, and incremental verbs which are unspecified for telicity, e. g. eat, write. Based on the analysis of English 
and other Indo-European languages it has been claimed that the referential status of the direct object of unspecified verbs is crucial to the interpretation of them as telic or atelic. Telicity is claimed to be a property of VPs, not just the verb in these cases. Krifka (1989) claims that the direct object must be "quantized", i. e. either have a specific referent, as in (10a) or signal a specific amount, as in (10a'). This appears to be the case in Lakhota; in (10a) there is a specific direct object and the interpretation of the clause is telic, whereas in $(10 \mathrm{~b})$ there is a non-specific object, and the interpretation is atelic. In (11) there is an example of a specific quantity, analogous to (10a').

(11) Wičháša ki oápȟe wayží (imáhel) tȟaspáy núppa Ø-Ø-yúte. man the hour one (within) apple two INAN-3sgA-eat 'The man ate two apples in/ ${ }^{*}$ for an hour.'

Thus, at first glance Lakhota appears to work like English in this regard.

Unlike English, however, the interpretation of a predication as telic or atelic is not a property of the VP and does not necessarily depend on the undergoer NP alone, for two reasons. First, Lakhota lacks a VP as a constituent in its clause structure, as shown in Van Valin (1987); there is no evidence that the verb and direct object form a constituent, as Lakhota fails all of the constituency tests for VPs. If factors beyond the verb are involved, as seems to be the case, then one would have to describe telicity as a property of the clause rather than the VP. Second, and more important, NP arguments need not occur, due to the headmarking nature of the language, as shown in (4a', b'), (6) and (7c), and therefore in such cases the telicity interpretation of the clause cannot depend on the status of the undergoer as an independent NP. Rather, it is a function of the coding of the argument on the verb, the temporal phrase accompanying it, or an independent expression of completion. A minimal pair based on verb coding is given in (12).

a. Wičhínčala ki oápȟe wayží wa-Ø-yáwa. girl the hour one NSO-3sgA-read 'The girl read for an hour.'

b. Wičhínčala ki oápȟe wayží Ø-Ø-yawá. girl the hour one INAN-3sgA-read 'The girl read it in an hour.'

The only difference between these two examples is the coding of the non-actor argument on the verb. In (12a) it is expressed by the non-specific object prefix $w a-$, which detransitivizes the verb and yields an atelic reading, as indicated by 
the translation of oápȟe wayži 'one hour' as 'for an hour'. In (12b), on the other hand, the verb is transitive with a specific undergoer, and the translation of the temporal phrase is 'in an hour'.

This effect can be cancelled, however, by the addition of an explicit temporal phrase, as in (13), with the added clause in brackets confirming the (a)telic interpretation of the first clause.

a. Hokšlla ki oápȟe wayží imáhel w-Ø-óte [éyaš w-ól

boy the hour one within NSO-3sgA-eat [but NSO-eat

Ø-iglúštaク-šni].

3sgA-finish-NEG]

'The boy ate in an hour [but he didn't finish eating].'

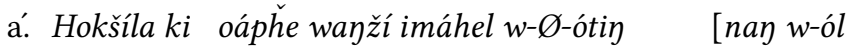

boy the hour one within NSO-3sgA-eat [and NSO-eat

Ø-iglúštay].

3sgA-finish]

'The boy ate in an hour [and he finished eating].'

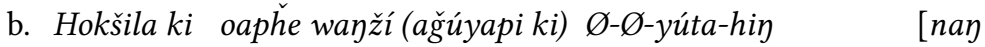

boy the hour one bread the INAN-3sgA-eat-CONT [and

Ø-yúl Ø-iglúštay].

INAN-eat 3sgA-finish]

'The boy was eating it (the bread) for an hour [and he finished eating it].

b. Hokšila ki oapȟe wayží (ağúyapi ki) Ø-Ø-yúta-he

[éyaš

boy the hour one bread the INAN-3sgA-eat-CONT [but

Ø-yúl Ø-iglúštaク-šni].

INAN-eat 3sgA-finish-NEG]

'The boy was eating it (the bread) for an hour [but didn't finish eating it].

In (13a, a') imáhel 'in, within' is added to the temporal expression together with the detransitivized form of the incremental verb yútA 'eat', wót $A$, and one possible reading is atelic, as (13a) makes clear. However, a telic reading is also possible, as (13a') shows. When -hay 'continuative' is added to the transitive form with a specific undergoer, as in $\left(13 \mathrm{~b}, \mathrm{~b}^{\prime}\right)$, one possible result is an atelic reading, as the compatibility with the second clause in (13b') shows, despite the specific undergoer. The telic reading is still possible, however, as (13b) shows. Hence in 
Lakhota a detransitivized verb with the non-specific object prefix is not necessarily atelic, and an incremental transitive verb with a specific undergoer is not necessarily telic. Verb morphology signaling the referentiality of an argument ( $w a$ - 'non-specific object' prefix) or signaling the temporal properties of the event (- $h A \eta$ 'continuative') can affect the interpretation of telicity in Lakhota. To unequivocally indicate that an incremental process is telic, the verb iglústan 'finish' can be added, as in (14).
a. Hokšíla ki oápȟe čik’ála wikčémna (imáhel) agúyapi ki Ø-yúl boy the hour little ten within bread the INAN-eat Ø-iglúštay. 3sgA-finish
'The boy finished eating the bread in ten minutes.'

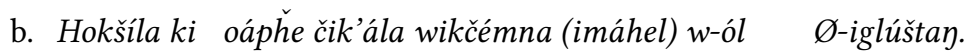 boy the hour little ten within NSO-eat 3sgA-finish 'The boy finished eating in ten minutes.'

Both sentences express that the action of eating was finished in ten minutes, differing in whether the things eaten are specified or not.

There are inherently telic incremental verbs in Lakhota, the prime example being thebyÁ 'devour, eat up'. It can co-occur with yútA as in (15) (NLD: 545).

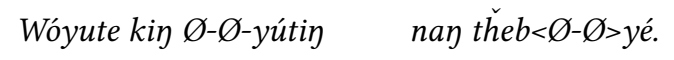

food the INAN-3sgA-eat and devour $<$ INAN-3sgA $>$

'He ate the food until he consumed it.' [Lit.: 'He ate the food and devoured it.']

Sentences like $\left(13 b^{\prime}\right)$ are not possible with tȟebyÁ 'devour'.

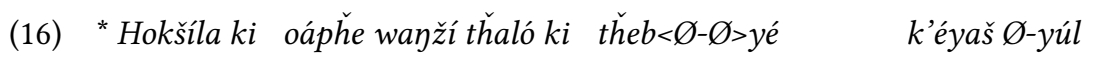
boy the hour one meat the devour $<$ INAN-3sgA $>$ but INAN-eat Ø-iglúštaク-šni.

\section{3sgA-finish-NEG}

'The boy devoured/ate up the meat but didn't finish eating it.'

Interestingly, theby $\bar{A}$ can take the non-specific object prefix $w a$-, yielding wathébyA meaning 'to consume things by eating, eat things up, to devour things' (NLD: 628), i. e. unspecified objects are being eaten to completion. This is similar to the meaning expressed in (13a), in which the things being eaten are left unspecified but the eating is completed. 
We have thus far concerned ourselves with transitive incremental verbs and the specificity status of their object, but there are intransitive incremental verbs which enter into telicity alternations, namely verbs of motion like run and walk. In English such verbs are sensitive to the type of PP that accompanies them, as illustrated in (17).
a. The boy ran to the park in/for an hour.
b. The boy ran in the park for ${ }^{*}$ in hours.

Run to the park is telic, since the motion to a specific goal (the park) is completed in an hour. A for-PP is not impossible with this form, but it does not have the relevant meaning; it can mean either that the boy ran back and forth to the park for an hour (iterative telic) or that he ran to the park and stayed there for half an hour (length of the result state, not the action of running). Run in the park, on the other hand, lacks a goal of any kind and merely expresses the location of the running, which is unbounded, hence the impossibility of an in-PP and the possibility of adding and he's still out there running felicitously to (17b). Lakhota can code this contrast, but it does not involve a difference in postpositions, as (18) shows.

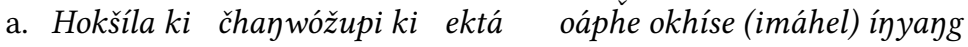 boy the park the at/to/in hour half (within) run $i<\varnothing>$ húnni. arrive.there $<3 \mathrm{sgA}>$ 'The boy ran to the park in half an hour.'

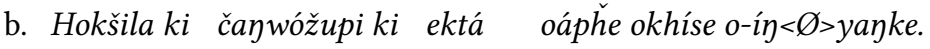 boy the park the at/to/in hour half in-run $<3 \operatorname{sgA}>$ 'The boy ran in the park for half an hour.'

In both sentences the $\mathrm{PP}$ is čhaywóžupi ki ektá 'at/in/to the park', ektá being neutral between location and goal meanings. To express motion to a goal, the manner of motion verb íyankA 'run' is combined with the verb ihúnni 'to arrive there, reach a destination' (NLD: 209), which expresses the completion of the action by the arrival at the destination. No such verb occurs in (18b), in which the manner of motion verb takes the locative prefix $o^{-}$'in', yielding a verb meaning 'to run around, run about, to run inside' (NLD: 414). The $o$ - prefix and the lack of a destination verb determine the interpretation of ektá as 'in' rather than 'to'. The locus of the expression of telicity with verbs of manner of motion in Lakhota is the verbal complex, not the accompanying PP, as in English. 
In sum, while the default interpretation of an incremental verb like yútA 'eat' is atelic with a non-specific object and telic with a specific object, as coded minimally on the verb itself, these defaults can be overridden by explicit temporal phrases or expressions of completion or non-completion within the clause. With motion verbs telicity is not signaled by the type of PP accompanying them but rather by the verbal complex directly.

\section{The encoding of specificity and definiteness in Tagalog}

Tagalog is one of the main languages in the Philippines. Basic sentences are predicate-intial. Dynamic and stative predicates usually appear with an affix which indicates the PSA (priviliged syntactic argument, cf. Van Valin \& LaPolla 1997) of the sentence. The affixes are commonly divided into actor voice affixes (maka-, um-, mag-, mang-) and undergoer voice affixes ( $\left.m a-, i^{-},-i n,-a n\right)$, as shown in (19a) and (19b). Philippine linguists also designate these affixes as 'focus affix', i. e. affixes focusing on the 'sentence topic' (the ang-marked argument) by indicating its thematic role. In addition to voice, verbal predicates may be marked for mood by the realis prefix in- (often realized as an infix or fused with a preceding nasal), and for aspect by prefixal CV-reduplication of the verb stem to express imperfectivity. The opposite values for mood and aspect are morphologically unmarked. Undergoer voice forms of realis verbs do not exhibit the undergoer voice suffix -in, so that without further voice marker, the realis form of a verb is always understood as undergoer voice, $\mathrm{cf}$. (19b).
a. Nag-basa ang bata ng libro. AV.RLS-read NOM child GEN book
'The child read a/some book.'
b. B<in>asa ng bata ang libro. $<$ RLS $>$ [uv] read GEN child NOM book 'A/The child read the book.'

Kroeger (1993) views the markers as case particles and labels them as ang: Nom, $n g$ : Gen, sa: DAt. Personal names take their own set of markers as Table 2 shows.

It has been a matter of debate whether the common noun-marking particles ang, $n g$ and $s a$ are truly determiners. Reid (2002) argues against this view, while Paul, Cortes \& Milambiling (2012) and Himmelmann (to appear) put forward convincing arguments in favor of the analysis of $a n g$ and $n g$ as determiners. When a language has a number of determiners, it can be suspected that they serve to 


\begin{tabular}{l|l|l|l} 
& Nominative & Genitive & Dative \\
\hline Common nouns & ang & ng & sa \\
Personal names singular & si & ni & kay \\
Personal names plural & sina & nina & kina
\end{tabular}

Table 2: Tagalog noun markers

express different degrees of referentiality. At least since Bloomfield (1917), it has been stated that ang-marked undergoer arguments tend to be associated with a definite/specific interpretation (cf. 19b), while $n g$-marked undergoers are typically interpreted as indefinite/non-specific (cf. 19a). However, it is not possible to have more than one ang-marked argument in a clause. As the sentences in (19) exemplify, the case marking of the arguments correlates with the voice marking of the verb. In actor voice (AV) sentences undergoers are marked by $n g$, and actors are marked by ang, while it is the other way around in undergoer voice (UV) sentences

The notions of definiteness and specificity are usually not formally defined in papers on Tagalog, but there seems to be a tacit consensus among Philippinists that definites establish an 'identifiable' and 'familiar' referent and express an assertion or presupposition of existence and uniqueness (cf. Givón 1973, Heim 1991 and others) with respect to their referent, while specificity is viewed as a weaker form of definiteness, in the sense that specific arguments are only associated with a presupposition of existence, but not necessarily with one of uniqueness.

Francisco de San José (1610) is quoted as the first to be associated with the claim that an indefinite undergoer cannot be ang-marked, while a definite undergoer has to be ang-marked. The latter claim has been refuted repeatedly. A list of contexts and constructions licensing a specific or even definite interpretation of $n g$-marked undergoer arguments can be found in MacLachlan \& Nakamura (1997), among others. They mention for example the recent perfective form of verbs (which does not require ang-marking on any argument in contrast to other verb forms), applicative constructions (under which they subsume beneficiary voice, recipient voice, instrumental voice) as well as actor sentences, in which the actor precedes the predicate licensing the $n g$-marked undergoer, as in (20a). Further examples of specific and definite undergoers in AV sentences are given in (20b-f). 
(20) a. Siya ang naka-kita ng aksidente.

3sgNOM NOM AV.RLS-see GEN accident

'He is the one who saw the accident.'

(Schachter \& Otanes 1972)

b. At kaya gusto ko-ng ma-nalong award na ito. and so want 1 sgGEN-LK AV-win GEN award LK this 'And so I want to win this award [=Comedy actress award].' (http://m.pep.ph/moblie/news) ${ }^{6}$

c. Hindi ba kayo nag-kita ng asawa ni Col. Adante? NEG Q 2plNom AV.RLs-see GEN spouse GEN Col. Adante 'Have you not met Col. Adante's wife?' (http://www.pinoyoexchange.com/formus/printthreadphp?t= $345875 \& p p=40 \&$ page $=43$ )

d. Nag-da dala siya ng Bible. AV.RLS-IPFV carry 3sgNOM GEN Bible 'He is carrying the Bible.' (pc. Reyal Panotes)

e. Mag-alis $k a \quad n g$ (iyon-g) sapatos bago $\quad p<u m>a s o k n g$ AV.IRR-leave 2sgNOM GEN (2sg-LK) shoe before < AV>enter GEN bahay.

house

'Take off (your) the shoes before you enter the house.' (www.seasite.niu.edu/Tagalog/.../diction.htm)

f. K<um>a kain sila ng kanila-ng sandwich. $<\mathrm{AV}>_{[\mathrm{RLS}]}$ IPFV $\sim$ eat 3plNOM GEN 3pl-LK sandwich 'They are eating their sandwiches.' (www.rosettastone.co.jp/.../RSV3_CC_Filipino)

The examples (20c) and (20d) exhibit undergoers with a semantically definite reference (Adante's wife, the Bible), while (20e, f) contain possessed undergoers, where the possessors are anaphoric pronouns whose reference is specific due to the argument in the sentence that binds them. Last, but not least (20a), (20b) and (20e) show $n g$-marked undergoers that receive definite reference due to the given context. The data in (20) provide good evidence that the marker $n g$ is not restricted to indefinite/non-specific contexts. In particular, (20b) shows that

6 (20)b and c were pointed out in a draft by Sabbagh (2012) 
it would not make sense to attribute a lack of specificity to $n g$, when it may cooccur with a demonstrative pronoun. The marker is thus best analysed as neutral with respect to referentiality (cf. Latrouite 2011), as it may be used to mark semantically and pragmatically definite arguments in the sense of Löbner (1985).

But how about the marker ang? Based on the data above one could conclude with Schachter (1976) that 'not every definite NP is a [sentence (AL/RVV)] topic, but every [sentence (AL/RVV)] topic is definite.' However, as Adams \& ManasterRamer (1988), Law (2006) and others have shown the Definiteness Restriction seems to be too strong to correctly predict the distribution of ang-and $n g$-marked undergoers even in this limited sense, so that it has become common to refer to ang as a specificity and not as a definiteness marker (cf. Himmelmann 2005). Law (2006) claims that ang-marked arguments do not even consistently fulfill the requirement of specificity. He points out that in the example in (21a) the existence of ang mali ('mistake') is not assumed by the speaker. Similarly in (21b) and (21c), the reference of the ang-phrase is neither predetermined nor mediated by referential anchoring to another discourse item.

(21) Non-specific ang-phrases

a. Basa-hin mo ang libro at sabi-hin mo sa akin, kung read-UV 2sgGEN NOM book and tell-UV 2sgGEN DAT 1sgDAT if ma-ki kita mo ang mali sa libro. UV.STAT-IPFV visible 2sgGEN NOM mistake DAT book 'Read the book and tell me, whether you see a(ny) mistake in the book.' (Law 2006: 163)

b. Maari na niyan-g sabi-hin ang anuman dito. possible LK 3sgGEN-LK say-UV NOM whatever here 'He can say anything here.'

(May hiyas pa sa liblib, Ronnie M. Halos, Pilipino Star Ngayon, August 12, 2010)

c. Gamit-in mo (ang) kahit (na) anuma-ng pinggan. use-uv 2sgGEN NOM any/even LK whatever-LK dish 'Use any dish!'

(Schachter \& Otanes 1972: 534)

If ang is not a specificity marker, then the question arises as to why ang-phrases are preferably understood as specific. In Latrouite (2011), it is suggested that the 
tendency to interpret ang-phrases as specific can be traced back to the interaction of (i) the function of voice marking, (ii) information flow in Tagalog basic sentences, and (iii) the fact that ang most likely evolved from a demonstrative pronoun (Reid 1978). All three factors contribute to the preferred interpretation of ang-phrases as specific, even if they may not enforce that ang-marked arguments must be specific in all contexts, as its primary function is the marking of the PSA. Another approach would be to assume a broader notion of specificity. It should be noted that the quantifiers used in the translations in (21) are high on the Quantifier Hierarchy (cf. Ioup 1975, Kuno et al. 1999) with respect to individuation, so that in a broader sense of the term the respective phrases could still be argued to fit the label 'specific' or at least 'more specific' in comparison to other quantified phrases. Disregarding this debate, if today's ang-marking with verbal predicates is analysed as the result of a grammaticalisation process that led to the development of a syntactic pivot marker, then the reasons for the choice of the ang-marked PSA are quite naturally based on a number of semantic, syntactic and pragmatic considerations (cf. Latrouite 2011), so that the role of referential properties of the undergoer argument may become less important for their distribution, at least if nothing hinges on the referentiality on a higher level like the level of event-structure. Note that the verbs in this section were not of the incremental type. Important for this paper is the fact that both case markers may mark definites, but that only for the marker ang definiteness is the default assumption without further co(n)text.

\section{Tagalog verbs, voice marking and telicity}

It has long been known that with a number of incremental verbs actor voice forms tend to receive an activity reading, while undergoer voice forms, more specifically patient voice forms, receive an accomplishment reading, as the sentences in (22) and (23) show.

(22) Activity readings with actor voice

a. S<um>ulat si Pedro ng liham.

$<\mathrm{AV}>_{[\mathrm{RLS}]}$ write NOM Pedro GEN letter

'Pedro wrote part of a letter/ letters.'

b. L<um>angoy ka sa ilog.

$<\mathrm{AV}>_{[\mathrm{RLS}]}$ Swim 2sgNOM DAT river

'Swim in the river.' 
c. K<um>ain ako ng isda. $<$ AV $>_{[\mathrm{RLS}]}$ eat 1 sgNOM GEN fish 'I ate (a) fish/fishes.'

d. <Um>akyat ako ng/sa bulog. $<$ AV ${ }_{\text {[RLs] }}$ go.up 1sgNOM GEN/DAT mountain 'I climbed on a/the mountain.'

(23) Accomplishment readings with undergoer voice
a. S<in>ulat ni Pedro ang liham. $<$ RLS ${ }_{[\text {uv] }}$ write GEN Pedro NOM letter 'Pedro wrote the letter.'

b. L<in>angoy mo ang ilog. $<$ RLS $>_{[\mathrm{uv}]}$ Swim 2sgGEN NOM river 'Swim (across) the river (= from one side to the opposite side).'

c. K<in>ain ko ang isda. $<$ RLS $>_{\text {[uv] }}$ eat 1 sgGEN NOM fish 'I ate the fish.'

d. <In>akyat ko ang bulog.

$<$ RLS $>$ [uv] go.up 1sgGEN NOM mountain

'I climbed the mountain (= all the way up to the top of the mountain).'

Saclot (2011: 159), who investigates incremental verbs in Tagalog, takes up this point and states that the AV form of these verbs is inherently atelic and therefore "enforces an indefinite/partitive/bare plural interpretation on the patient", while the UV form is inherently telic, and enforces a specific/definite reading of the undergoer and consistently fails her cancellation and continuity tests. Saclot's conclusion ist that "in Tagalog it appears to be telicity [= the telicity associated with the undergoer voice (AL/RVV)] that triggers the interpretation of the patient argument [as definite (AL/RVV)]." Saclot restricts her claim regarding AV-forms explicitly to incremental verbs, which is necessary, since, as we have seen in the previous section, it would not be possible to uphold it with respect to all verb classes. Note, however, that indefiniteness per se does not clash with telicity. There is no difference in telicity between He ate the apple and He ate an apple, so it is not quite clear why an atelic verb form should induce an indefinite reading.

In order to support her claim with respect to the inherent (a)telicity of the voice forms, Saclot (2011) contrasts the two sentences in (24a) and (24b) and finds that the undergoer voice sentence cannot be continued by the phrase pero hindi niya 
natapos ('but he did not finish it') (24b), while the actor voice sentence can be continued by this phrase (24a). The demonstrative pronoun given in brackets was added by our consultants.

a. G<um>awa si Ben ng isa-ng bangka pero hindi niya (ito) $<\mathrm{AV}>_{[\mathrm{RLS}]}$ make NOM GEN one-LK boat but not 3sgGEN this.NOM na-tapos.

UV.STAT-finish

'Ben made a boat, but he did not finish (it).'

b. \#G<in>awa ni Ben ang isa-ng bangka pero hindi niya (ito) $<$ UV $>_{[\mathrm{RLS}]}$ make GEN NOM one-LK boat but not 3sggen this.NOM na-tapos.

UV.STAT-finish

'Ben made the one boat, but he did not finish (it).'

In contrast to Saclot's judgements, three of our four consultants accept both sentences as well-formed. One remarked on the fact that the boat relates differently to the event in both cases. For this consultant the AV-form implies that a boat was built from scratch, while the UV-form connotes that Ben worked on a specific boat (e. g. repaired or painted it) that had already existed. This means that the interpretation of the PSA undergoer in the undergoer voice sentence is affected by the subject property of 'independent existence' (Keenan 1976). Interestingly, the UV-form of the verb is then no longer interpreted as one of creation. Note that matapos is ambiguous between 'to finish' and 'to stop' so that the test may be not all that conclusive. In case the test is considered conclusive, however, (25) shows that the AV-form, which is always understood as one of creation, may also be interpreted as telic.

G<um>awa si Ben ng isa-ng bangko at na-tapos nang mabilis $<\mathrm{AV}>_{[\mathrm{RLS}]}$ make NOM GEN one-LK boat but UV.STAT-finish MOD quick niya ito.

3sgGEN this.NOM

'Ben made a boat, and he quickly finished it.'

Two consultants come to a similar conclusion regarding strictly incremental predicates like the verb for to drink in (26), i. e. they accept both voice forms with the reading that the event was not completed. The difference between the verbs for 'to finish', matapos and maubos, is that the former is temporal, while the latter is about 'exhaustion'. 
a. Um-inom si Ben ng beer pero hindiniya (ito) na-ubos. $\mathrm{AV}_{[\mathrm{RLS}]}$-drink NOM GEN beer but not 3sgGEN this.NOM UV.STAT-finish 'Ben drank (a) beer, but he did not finish (it).'

b. ?? In-inom ni Ben ang beer perohindiniya (ito) na-ubos. $\mathrm{UV}_{[\mathrm{RLS}]}$-drink GEN NOM beer but not 3sgGEN this.NOM UV.STAT-finish 'Ben drank the beer, but he did not finish (it).'

With respect to the continuation test, our consultants agree with Saclot's judgements regarding the examples in (27). Apparently the continuation phrase of the UV sentence sounds worse, while it sounds slightly better with the AV form. Once again, the undergoer phrase Nihongo gets reinterpreted by our consultants. Obviously, in an attempt to get a clearly individuated and bounded reading of the ang-marked undergoer, one consultant suggests that ang Nihongo is understood as a course (which Ben attended to become fluent). The continuation reading then is weird, as the quantifier 'a lot' is taken to refer to the course and would result in the contradictory reading that 'Ben studied the course, but still has to study a lot (of the course).'

a. Nag-aral si Ben ng Nihongo pero marami pa ring dapat aral-in. AV.RLS-study NOM GEN Japanese but much still also must learn-UV 'Ben studied Japanese, but he still has to learn a lot.'

b. ?? In-aral ni Ben ang Nihongo pero marami pa ring dapataral-in. RLS$_{\text {[uv] }}$-study GEN NOM Japanese but much still also must learn-UV 'Ben studied (the) Japanese (course), but he still has to learn a lot.'

Saclot compares the two verb forms in the main clause. The undergoer voice form aralin in the subordinate clause translated as 'but he still has to learn a lot (a. of Japanese/ b. of the Japanese course)' is of interest, too. One could not have the actor voice form of 'to learn' in this sentence without changing the meaning significantly. The quantifier marami can only refer to the argument identified on the verb via the voice affix, so that the actor voice sentence marami pa ring dapat magaral can only mean 'many still have to learn.' Therefore, the only way one can get a quantifier like 'a lot' to modify the undergoer argument is by choosing undergoer voice.

There is further evidence that actor voice forms may very well appear in telic predications. The following actor voice sentences in (28a) and (28b) contain phrases introducing a measure for the length of the path traversed by the actor which 
can be directly mapped onto the run-time of the event. The interpretation therefore is telic. Note that the PSA of the undergoer voice form of 'to run' in (28) may be a path or an event associated with a path like a marathon, but does not have to be. According to Nolasco (2005), the undergoer may just as well denote an object that is conceived as a goal motivating the running event (cf. Latrouite 2012), as in (28d).

a. Nag-takbo ako ng marathon.

AV.RLS-run 1sgNOM GEN marathon

'I ran a/some marathon'

b. L<um>angoy siya ng 10 miles para maka-rating $n g$ $<\mathrm{AV}>_{[\mathrm{RLS}]}$ Swim 3sgNOM GEN 10 miles for AV.POT-arrive GEN pinakamalapit na beach.

nearest LK beach

'He swam ten miles to reach the nearest beach.'

c. Takbu-hin mo ang marathon!

run-UV 2sgGEN NOM marathon

'Run the marathon!'

(cf. http://www.scribd.com/doc/6784539/salita)

d. Takbu-hin mo ang Marlboro.

run-uv 2sgGEN NOM Marlboro

'(You) run to (get) the Marlboro!'

(cf. Nolasco 2005: 215) ${ }^{7}$

Note that the difference between (28a) and (28c) is one translated in terms of definiteness rather than in terms of telicity, stressing the point made in Filip (1993/1999) that definiteness and telicity should be kept apart as two independent notions (see also Fleischhauer \& Czardybon, this volume). The data so far suggest that actor voice forms of incremental verbs are not restricted to atelic predications, while undergoer voice forms of strictly incremental verbs seem to be at least clearly preferred with telic interpretations by many consultants. The very preliminary study in this paper shows that there may be differences depending on whether a verb is or is not strictly incremental. One could then argue that the difference between telic actor voice sentences and telic undergoer voice sentences is that the former require further context knowledge to calculate the telicity, while the latter do not, as telicity is the default for them.

7 According to English (1986), the form would have to be takbuhan. 
Summing up the findings in this section, it appears to be right that as a default the undergoer argument receives a specific and individuated reading with undergoer voice verbs. This reading may be viewed as 'imposed' by the undergoer voice form of incremental verbs in that the undergoer voice form requires the undergoer to be prominent to become the PSA, and with incremental verbs an undergoer that measures out an event and thereby influences the aspectual reading of the verb, i.e. an undergoer that is event-structurally salient, is more prominent than one that does not have these properties. However, we have seen that the default for ang-marked undergoers is also that they get a specific and individuated reading with activity and other non-telic verbs, so the argument that the inherent telicity of undergoer voice forms enforces a specific interpretation is not particularly strong. The judgements in this section seem to suggest that for certain verbs it is possible to cancel the telicity or deny it via co(n)text without changing the referential reading of the undergoer. If this is so then their telicity may best be viewed as an implicature. In the case of actor voice forms it is very clear that they are not inherently restricted to a particular reading, i. e. to atelicity, given that they do not require a particular reading on their undergoer argument which may be specific or non-specific. In terms of a decompositional approach one would certainly assume that the bare verb stem is not specified for (a)telicity, but may be built upon to achieve telic readings, either by marking that the undergoer argument is the most prominent referentially and in event-structural terms via the undergoer voice affix, or in the case of actor voice through co(n)text.

\section{Implications for a theory of telicity}

This paper has addressed the issue of referentiality and the interpretation of incremental predicates as telic in two unrelated and typologically very different non-Indo-European languages, Lakhota and Tagalog. Our investigation has shown that while having a referential undergoer often, indeed usually, leads to a telic interpretation of an incremental predicate, it does not necessarily generate a telic reading with such verbs. This supports the arguments made in Filip (2004) against the claim by Borer (2004) regarding a purported correlation between definite direct objects and telic interpretations. Filip argues that "articles, possessive pronouns, certain quantifiers or the accusative suffix in the direct object NP/DP in Germanic languages cannot be claimed to encode telicity, because they are not consistently and in all of their occurrences linked to the telicity of a VP, but rather 
may serve as just one among other contributing factors that together result in a telic interpretation of a VP" (2004: 98-99).

We have found that there are a number of factors that affect the interpretation of a verb as telic or atelic, no one of which is absolutely decisive. In Lakhota, the specificity of the undergoer argument, which may be coded exclusively by affixes on the verb, is a significant factor. In Tagalog, verbal voice also serves as an important factor in the determination of default telicity with incremental verbs. Its primary function, however, is to identify the thematic role of the PSA of the sentence, which, without further context, is attributed all the prototypical properties of subjects such as specificity, individuation and independent existence mentioned in Keenan (1976). In the presence of an undergoer argument as PSA expressed by a noun (phrase) with the appropriate lexical semantic properties to be interpretable as quantized, a telic reading ensues as the default. As we have seen, this default may be overridden by context or grammatico-semantic considerations. Indeed, Filip (1993/1999) argues that incremental verbs like eat are aspectually undetermined. One technical solution would be to posit default interpretations in specific grammatical contexts: incremental verb + quantized object/undergoer voice $=>$ telic, incremental verb + non-quantized object/actor voice $=>$ atelic. These can, as we have seen in both languages, be overridden, and this raises the issue of how robust these defaults are. That would seem to be a function of the lexical semantic properties of the verb and the relevant argument(s), together with pragmatic principles; and thus very much in line with what Filip (2004) notes with respect to the possible interpretation of a mass noun as having a definite quantity, "[i]f a definite description consisting of the and a mass or plural noun has a 'quantity' interpretation it is not determined by the grammar, but rather depends on pragmatic principles of interpretation and world knowledge" (2004: 97).

Important throughout the paper was the role of noun phrase interpretation or noun phrase referentiality for the interpretation of the verb. While the referentiality of the undergoer argument may be recognized as a factor influencing - but not finally determining - the verbal interpretation, it was shown for both languages that the interpretation of noun phrase markers may also be subject to default reasoning that can be overridden.

Throughout the paper it was shown that the referentiality aspect of definiteness was important for telic interpretations. This property, referential uniqueness, is indispensable for the quantization of the undergoer, especially with mass 
nouns and bare plurals, and this supports the analysis of uniqueness as the essential property of definiteness made in Löbner (1985).

\section{Bibliography}

Adams, K. \& A. Manaster-Ramer. 1988. Some questions of topic/focus choice in Tagalog. Oceanic Linguistics 27. 79-101.

Austin, P. \& J. Bresnan. 1996. Non-configurationality in Australian Aboriginal languages. Natural Language and Linguistic Theory 14. 215-68.

Bloomfield, L. 1917. Tagalog texts with grammatical analysis. University of Illinois Studies in Language and Literature 3. 157-278.

Borer, H. 2004. Structuring sense. Oxford: Oxford University Press.

DeReuse, W. 1994. Noun incorporation in Lakota Siouan. International fournal of American Linguistics 60. 199-260.

English, J. 1986. Tagalog-English dictionary. Manila.

Filip, H. 1993/1999. Aspect, situation types and noun phrase semantics. Garland Publishing, Inc. [PhD Thesis 1993].

Filip, H. 2004. The telicity parameter revisited. In R. Young (ed.), Proceedings of SALT XIV, 92-109. Ithaca/NY, Cornell University.

Filip, H. \& S. Rothstein. 2005. Telicity as a semantic parameter. In J. Lavine, S. Franks, H. Filip \& M. Tasseva-Kurktchieva (eds.), Formal approaches to Slavic linguistics XIV. The Princeton University meeting, 139-156. Ann Arbor, MI: University of Michigan Slavic Publications.

Fleischhauer, J. \& A. Czardybon. 2014. Definiteness and perfectivity in telic incremental theme predications. This volume.

Givón, T. 1973. Opacity and reference in language: An inquiry into the role of modalities. In J. Kimball (ed.), Syntax \& semantics 2, New York NY: Academic Press.

Heim, I. 1991. Articles and definiteness. In A. v. Stechow \& D. Wunderlich (eds.), Semantics: An international handbook of contemporary research, Berlin: de Gruyter. Published in German as "Artikel und Definitheit".

Himmelmann, N. 2005. Tagalog. In K. A. Adelaar \& N. P. Himmelmann (eds.), The Austronesian languages of Asia and Madagascar, 350-376. London: Routledge.

Himmelmann, N. to appear. Notes on noun phrase structure in Tagalog. Ioup, G. 1975. Some universals for quantifier scope. In J. Kimball (ed.), Syntax and semantics, vol. 4, 37-58. New York: Academic Press. 
Keenan, E. 1976. Towards a universal definition of "subject”. In C. N. Li (ed.), Subject and topic, New York: Academic Press.

Kratzer, A. 2004. Telicity and the meaning of objective case. In J. Guéron \& J. Lecarme (eds.), The syntax of time, 389-424. Cambridge/Mass.: The MIT Press.

Krifka, M. 1986. Nominalreferenz und Zeitkonstitution. Zur Semantik von Massentermen, Individualtermen, Aspektklassen. Munich, Germany: Universität München Dissertation.

Krifka, M. 1989. Nominalreferenz und Zeitkonstitution. Zur Semantik von Massentermen, Individualtermen, Aspektklassen. München: Wilhelm Fink Verlag.

Krifka, M. 1992. Thematic relations as links between nominal reference and temporal constitution. In I. A. Sag \& A. Szabolcsi (eds.), Lexical matters, 2953. Stanford: CSLI.

Kroeger, P. 1993. Phrase structure and grammatical relations in Tagalog. Stanford: CSLI.

Kuno, Susumu, Ken-ichi Takami \& Yuru Wu. 1999. Quantifier scope in English, Chinese and Japanese. Language 75. 63-111.

Latrouite, A. 2011. Voice and case in Tagalog: the coding of prominence and orientation. Düsseldorf: University of Düsseldorf dissertation.

Latrouite, A. 2012. Shifting perspectives. Paper read at the 12th International Conference of Austronesian Linguistics. Indonesia: Bali.

Law, P. 2006. Argument marking and the distribution of wh-phrases in Malagasy, Tagalog and Tsou. Oceanic Linguistics 45. 153-190.

Löbner, S. 1985. Definites. Journal of Semantics 4. 279-326.

MacLachlan, A. \& M. Nakamura. 1997. Case-checking and specificity in Tagalog. The Linguistic Review 14. 307-333.

Nolasco, R. 2005. What Philippine ergativity really means. Paper presented at Taiwan-Japan Joint Workshop on Austronesian Languages, National Taiwan University, Taipei, p. 215 - 238.

Paul, I., K. Cortes \& L. Milambiling. 2012. On Tagalog determiners. Talk given at AFLA19 in Taiwan.

Ramchand, G. C. 1997. Aspect and predication. The semantics of argument structure. Oxford: Clarendon Press.

Reid, L. 1978. Problems in the reconstruction of proto-Philippine construction markers. In S. A. Wurm \& Lois Carrington (eds.), Second international conference on Austronesian linguistics: Proceedings, fascicle I-western Austronesian. Pacific Linguistics Series C, No. 61, 33-66. 
Reid, L. 2002. Determiners, nouns, or what? Problems in the analysis of some commonly occurring forms in Philippine languages. Oceanic Linguistics 41. 295-309.

Rood, D. \& A. Taylor. 1996. Sketch of Lakhota, a Siouan language. In I. Goddard (ed.), Handbook of North American Indians: Language, vol. 17, 440-82. Washington: Smithsonian Institution: Smithsonian Institution.

Sabbagh, J. 2012. Specificity and objecthood in Tagalog. Manuscript- UT Arlington ling.auf.net/lingbuzz/001647/current.pdf.

Saclot, M. 2011. Event structure in Tagalog. University of Melbourne dissertation.

Schachter, P. 1976. The subject in Philippine languages: topic, actor, actor-topic, or none of the above. In C. Li (ed.), Subject and topic, 493-518. New York: Academic Press.

Schachter, P. \& F. T. Otanes. 1972. Tagalog reference grammar. Berkeley, CA.: University of California Press.

Ullrich, J. 2011. New Lakota dictionary [NLD]. Bloomington: Lakota Language Consortium. 2nd. Ed.

Van Valin, R. D. Jr. 1987. The role of government in the grammar of head-marking languages. International fournal of American Linguistics 53. 371-97.

Van Valin, R. D. Jr. 2013. Head-marking languages and linguistic theory. In B. Bickel, L. A. Grenoble, D. A. Peterson \& A. Timberlake (eds.), Language typology and historical contingency, 91-123. Amsterdam: John Benjamins.

Van Valin, R. D. Jr \& Randy LaPolla. 1997. Syntax: structure, meaning and function. Cambridge: Cambridge University Press.

Verkuyl, H. 1972. On the compositional nature of the aspects. Dordrecht: Reidel Publishing Co.

\section{Authors}

Anja Latrouite

Robert D. Van Valin, Jr.

Departement of Linguistics and Information Science

Heinrich-Heine-University Düsseldorf

\{latrouite,vanvalin\}@phil.hhu.de 